\title{
Studies in the genus Mycena in Finland
}

\section{Hintikka}

1. Introduction. The genus Mycena has in recent times been the subject of comprehensive monographs by $\mathrm{R}$ obert $\mathrm{K} \ddot{\mathrm{u} h \mathrm{~h} \text { er }}$ (1938) in Central Europe and by A l e x a nd e r H. S m it h (1947) in North America. Largely due to these works, this genus must be regarded as one of the best-known genera of agarics. In Finland, after the basic investigations of $\mathrm{P}$. A. K a r ste $\mathrm{n}$, the need for up-to-date revisions has become more and more apparent.

$\mathrm{K}$ a r s te $\mathrm{n}$ reported about 60 species of Mycena from Finland. After him, many new species have been found ( $T$ h e s l e ff 1920, La urila 1939, Ekl und 1943, Frey 1944, Stenlid 1947, Tuomikoski 1953, M a lmström 1960, Schul$\mathrm{m}$ a $\mathrm{n} \mathrm{n}$ 1961), totalling about 100 different names (see also $R$ a u t a vara 1947). However, a few of these are synonyms and some used by older authors are based on macroscopical description only and probably have new names derived from the anatomy of the basidiocarp.
2. Material and methods. The material which forms the basis of this study consists mainly of my collections, of which about 600 are obtained from the vicinity of Korso (24 $\mathrm{km}$ north of Helsinki) during the years $1954-62$ and about 200 from other parts of Finland. This material has been studied both in fresh and dried condition. In general, I have followed the field and laboratory methods described by S m it h (1947). The colour terms are according to $\mathrm{M}$ a e $\mathrm{rt} \mathrm{z}$ \& P a u l (1950). In addition, I have studied the specimens preserved in the herbariums of the University of Helsinki and a part of those of University of Turku, including P. A. $\mathrm{K}$ arsten's collections, for which I am indebted to Custos, Dr. H e ik ki Ro i$\mathrm{v}$ a i n e $\mathrm{n}$ and to the Assistant Prof,, Dr. $\mathrm{P}$ a a vo Ka 11 i o. Unfortunately, a considerable part of these collections could not be identified chiefly in lack of macroscopical descriptions, and are not mentioned here.

3. Some ecological considerations. In summer and early fall, before the regular mushroom

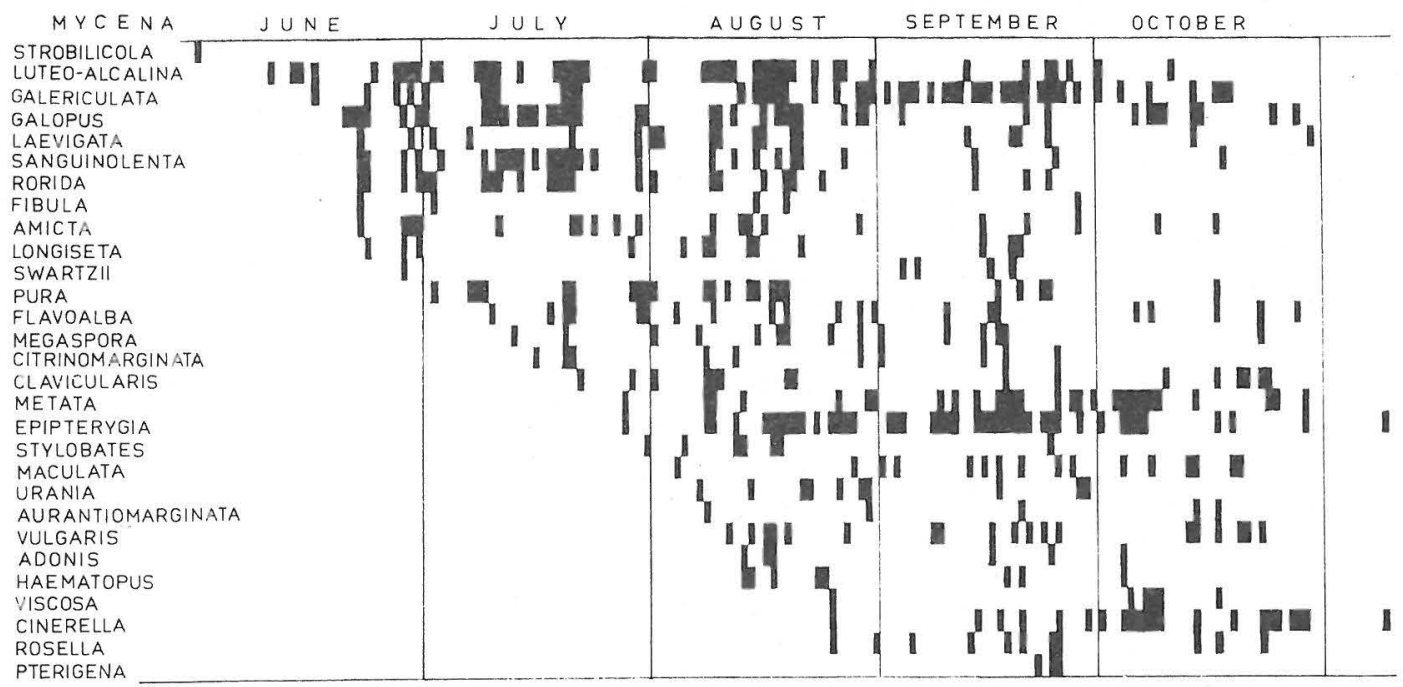

Fig. 1. Seasonal occurrence of some Mycena-species in the neighbourhood of Korso during the years $1954-60$. 
season in late August and in September, the genus Mycena forms a very prominent part of the mushroom crop in regard to the number of basidiocarps present. Most species appear before or during August (Fig. 1). It should be noted that only a few species occur in spring. According to $\mathrm{S} \mathrm{mith} \mathrm{(1.c.)} \mathrm{many}$ Finnish fall species occur in North America also in the spring and are usually absent in summer (e.g. Mycena longiseta). This phenological difference seems to be due to the higher summer temperature climate of America, since in the Alps, where the moisture conditions are more favourable than in America and in Fennoscandia, the species apparently follow the same pattern of appearance as in Finland.

In general most species have very definite habitat requirements, which are given in the species list below; the biotope classification is based on Finnish forest site types. In many cases they can be used as additional field characteristics, e.g. of the gray slimy species $M$. clavicularis occurs in dry pine forests in contrast to $M$. vulgaris, which grows usually in moist mossy spruce forests. Of the small species in group Filipedes, $M$. atroalboides is met with in most oligotrophic localities (dry lichen woods, Calluna and Vaccinium-type), $M$. metata is common in coniferous moss forests and $M$. iodiolens seems to be confined to rich grass-herb forests on mull soil. The most specialized lignicolous species seem to be $M$. galericulata and $M$. niveipes, which grow almost exclusively on rotten wood of deciduous trees, $M$. inclinata, which grows only on logs and stumps of Quercus, and $M$. laevigata, $M$. luteoalcalina and $M$. maculata, which are confined to rotten coniferous wood.

Although the material outside the area around Helsinki is based on trips of relatively short duration (1-2 weeks) during which not all species in a locality can be expected to be found, it seems that there are no major differences in the Mycena-flora between the different parts of Finland. The only species collected exclusively in North Finland is $M$. algeriensis and, on the whole, the dominant species there seem to be the same ones as in southern Finland. The oak forests on the southern coast of Finland have, however, some characteristic species not recorded elsewhere in our country, e.g. $M$. inclinata and $M$. erubescens.
Explanation of abbreviations: H: Botanical $\mathrm{Mu}-$ seum of the University, Helsinki, O.v. S.: O.v. Schulmann, P.A.K.: Pet ter August Karsten, R. T.: Risto Tuomikoski, Tur: Botanical Museum of the University of Turku, V.H.: the author, W. N.: Wolmar $\mathrm{Ny}$ b e r $\mathrm{g}$.

\section{Mycena Abramsii Murrill}

S m i t h 1947, p 239.

V. Bromarv, Framnäs (V.H.) Pyhäjärvi U.l., Vuotinainen (V.H.). — U. Tuusula, Ruotsinkylä and Hyrylä; Helsinki parish, Korso; Sipoo, Myyras (V.H.).- EH. Tammela (P.A.K., H.). - PS. Joroinen, Keriniemi (V.H.).

Occurs gregarious to subcaespitose usually on rotten twigs buried in soil in moist woods (often under alder) in June-September. In North America this species grows in hardwoods particularly in spring (S m it h l.c.). M. Abramsii, which has not earlier been reported from Finland is recognizable by its narrow spores, somewhat sulcate cap and by its relatively large size. Pleurocystidia were present in all collections.

Mycena acicula (Schaeff. ex Fr.) Kummer.

K ühner 1938, p. 602, S m ith 1947, p. 119.

U. Helsinki, Pasila, on rotten leaves in a herbrich forest, 24.VII 1952, (R.T.,H).

\section{Mycena adonis (Bull. ex Fr.) S.F. Gray}

K ühner 1938, p. 555, S m it h 1947, p. 177.

U. Helsinki parish, Korso; Tuusula, Ruotsinkylä (V.H.) ; Porvoo (W.N.). - EH. Tammela, Mustiala (K a r s te n 1889 , p. 83). - 6 collections.

Specimens studied fresh were found in mixed forests of Myrtillus-type, in most cases on places rich in litter.

\section{Mycena alba (Bres.) Kühner}

K ü h n e r 1938, p. 594.

U. Helsinki, on bark of a living deciduous tree, Dec. 19, 1960, leg. M. K o $\mathrm{r}$ h o n e $\mathrm{n}$.

\section{Mycena alcalina (Fr. ex Fr.) Kummer}

K ühne r 1938, p. 464, L a n g e 1936, Pl. 51 H. U. Tuusula, Ruotsinkylä (V.H.); Hyvinkää (R.T.,H). - EH. Tammela (P.A.K., H); Juupajoki (V.H.)

Grows more or less fasciculate on stumps of conifers. $M$. alcalina has been regarded as a common species in Finland ( $\mathrm{K}$ a r s t e $\mathrm{n}$ 1889, Thes leff 1920 , $\mathrm{R}$ a u t a va a r 1947). However, a part of the statements refer to $M$. luteoalcalina, which is distinctly more frequent than $M$. alcalina.

Bisporous form is met with several times in June and July. 


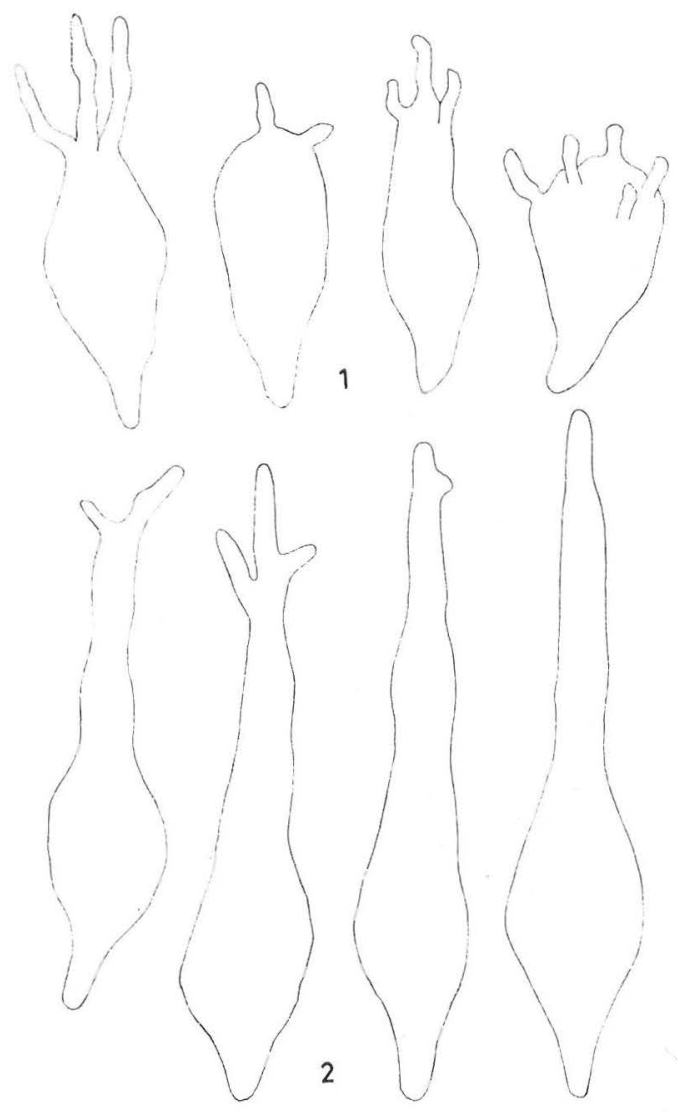

Fig. 2. Mycena alcalina (bisporous form). Cheilocystidia from the distal part (1) and from the proximal part (2) of the lamellum.

Thesleff's specimen from Viipuri in HMF collected from rotten oak wood belongs to the $M$. galericulata-group.

The form of the cheilocystidia varies greatly even in the same pileus. On the distal part of the gill edge they are often short, roundish, and a few with several obtuse projections, on the proximal part of the edge they are fusoid-ventricose, long-necked, and usually unbranched (Fig. 2). The same type of variation I have found in $M$. luteoalcalina. This phenomenon was especially common during the dry summer of 1959, which would suggest that it has some connection with the different humidity conditions under which the cystidia develop but is not related to the development of the carpophore.

\section{Mycena algeriensis $\mathrm{R}$. Maire}

R. M a ire in K ühner 1938, p. 490.

Pileus subcylindric to narrowly conic when young, then expanding to broadly and sharply conic, slightly sulcate and shining, striate when moist. Disc at centre blackish, then fading to blackishbrown to dark brown gray, extreme margin slightly paler; no yellowish shade. Odor faintly »alcalic». Lamellae whitish, moderate close, 20-26 reach the stipe, $2-3$ tiers of lamellulae, medium broad, under hand- lens hairy from pleurocystidia. Stipe fragile, blackish gray with a brownish cast, when young covered with abundant white fibrils.

Spores $10-11 \times 5-7 \mu$, basidia 4 -spored, cheilocystidia $60-75 \mu$ long, cylindric, blunt-ended and voluminous, pleurocystidia similar, abundant, 70$90 \mu$ long. The hyphae of the epicutis smooth, forming $20-35 \mu$ thick layer, hypodermis well developed, cells filled with gray pigment, the remainder consisting of closely interwoven hyphae.

KemL. Sodankylä village (V.H.). - InL. Inari, Ivalo, Toloskoski (V.H.).

Both collections were made on rotten wood (log and stump) of birch.

In light of the present material this species seems to be distinctly different from $M$. niveipes by having a hairy stipe, dark colors and obtuse pleurocystidia.

As far as I know, $M$. algeriensis has not been previously reported from Europe. It was described from Algeria by $\mathrm{R}$ en e $\mathrm{M}$ a ir e, where it grows on rotten wood of Quercus, Eucalyptus and Phillyrea. In North America it occours ( $\mathrm{S}$ m it h l.c.) in Ontario and in the northern United States on elm and alder logs.

\section{Mycena amicta (Fr.) Quél.}

Syn. M. Iris Berk.

K ühn e r 1938, p. 196, S m it h 1947, p. 61, L a n g e 1936, Pl. 50 C.

V. Bromarv, Framnäs (V.H.). - U. Tuusula; Helsinki parish (V.H.). - EH. Lammi, Evo (R.T., H); Nokia (P.A.K., H, as Mycena sp.); Tammela, Mustiala (K a r sten 1889). - PS. Joroinen, Keriniemi (V.H.). — PK. Pielisjärvi, Koli (R.T., H). - PP. Rovaniemi (V.H.).

Common in mossy spruce forests among needles and moss, sometimes also on rotten stumps and cones.

K a rsten (1889, p. 86) mentions $M$. amicta (as $\beta$ leucopsis) as a rare species from Mustiala. There are no later published records. It is easily recognizable by its hairy stipe, gelatinous pellicle of the pileus, and dark blackish blue base of the stipe. Most collections were light gray-brown without any more bluish colours.

Mycena atroalboides (Peck) Sacc.

Syn. M. sepia Lange? (M. L a n g e 1948, p. 379), M. vitrea Kühner ( $\mathrm{S} \mathrm{m}$ it h 1947, p. 281.)

Pileus $0.5-2 \mathrm{~cm}$ broad, at first obtusely conic- 
campanulate, becoming broadly conic and often with indistinct broad umbo in age, when young hoary, hygrophanous, when moist striate near to the centre, colour blackish on the disc, towards margin pale gray, usually without yellowish, brownish, or reddish colours. Context grayish, thin, smell when crushed reminiscent of that of cucumber or tomato blades, not of iodoform.

Gills pale gray, ascending, narrow, relatively close, adnexed. Stipe $4-6 \mathrm{~cm} \times 0.5-1.0 \mathrm{~mm}$, colour dark gray except about $5 \mathrm{~mm}$ broad zone at the apex, which is whitish or pale gray.

Spores $8-10 \times 3.5-4.5 \mu$, basidia four- spored, cheilocystidia numerous, clavate, covered with short rodlike projections, $12-15(-21) \mu$ broad, pleurocystidia similar, rare. Epicutis formed of narrow hyphae, the uppermost ones with rodlike projections, hypodermis distinct, cells elliptical, diam. 18-25 $\mu$, distinctly gray- brown, the remainder formed of 8-14 $\mu$ broad hyphae. Lam.-trama gray-brown. Clamp connections abundant.

U. Tuusula, Ruotsinkylä; Hyvinkää (V.H.). - EK. Luumäki, Taavetti (V.H.).

I have met this species in dry pine forests on gravel soil (Vaccinium or Calluna type), often in young pine plantations rich in litter. In my experience it is possible in the field to distinguish it from $M$. metata by its grayish colours and by its smell.

According to $\mathrm{S} \mathrm{mith} \mathrm{(l.c.)} \mathrm{the} \mathrm{gills} \mathrm{are} \mathrm{some-}$ times stained with reddish brown, which I have not been able to observe in my mushroom. The breadth of the cystidia are between the values given by $\mathrm{K} \ddot{\mathrm{uhn}} \mathrm{er}(11-25 \mu)$ and $\mathrm{S} \mathrm{mith}(6-12 \mu)$. It seems, however, that this difference is not taxonomically significant. - L u n d e 11 (L u n d e I 1 \& Nannfeldt 1942, p. 10) has collected $M$. sepia in Femsjö (Sweden) on similar habitat (»amongst needles, twigs, small Polytricha etc. on sandy soil at road-sides) and according to him Fries's $M$. filopes is probably identical with this fungus.

\section{Mycena atrocyanea (Batsch ex Fr.) Gillet.}

One collection from a grassy grazed open birchforest in Helsinki parish, Vantaa, 30.VIII 1952 (V.H.). Following notes were made on this material: Pileus $0.8-1.7 \mathrm{~cm}$ broad, conic-campanulate, neither striate nor glossy, deep pure black without any brownish colours. Lamellae moderately broad, adnexed, pallid, edge white. Stipe deep black, 3-4 $\mathrm{cm} \times 1 \mathrm{~mm}$. Spores $8.5-11 \times 4-6 \mu$, ellipsoid, basidia 4-spored, cheilocystidia fusoid-ventricose, neck straight, apice acute, $25-40 \times 11-14 \mu$, partly spherical and vesicular, diam. 15-18 $\mu$, pleurocystidia absent. Epicutis thin (about $10 \mu$ ), the uppermost hyphae with rod-like projections, hypodermis distinct, cells vesicular, diam. $20-35 \mu$, filled with dark pigment, the remainder consisting of colourless filamentous hyphae, lam.-trama slightly grayish. Oleiferous hyphae could not be detected either in pileus or in stipe.

Mycena aurantiomarginata (Fr.) Quél.

Syn. M. elegans (Fr. ex Pers.) Schroeter

K ühner 1938, p. 268, S m it h 1947, p. 198.

U. Helsinki, Vestersundom (R.T., H); Grankulla and Porvoo parish (W.N., H); Tuusula and Helsinki parish (V.H.), Hyvinkää, Jätinlinna (V.H.). - EH. Tammela, Mustiala (P.A.K., H).

Most collections are from spruce forests, usually of good quality (OMT). According to $\mathrm{K}$ a r s te $\mathrm{n}$ (1889) this species is common in South and Central Finland. F a v re (1948) records it from spruce forests in borders by bogs in the Jura mountains.

Some collections by $\mathrm{Karsten}$ and $\mathrm{Thes}-$ l eff in $\mathrm{H}$ labelled $M$. elegans have cystidia of $\mathrm{C} i$ liatae-type, and belong very probably to $M$. citrinomarginata.

\section{Mycena capillaripes Peck}

K ühner 1938, p. 403, S m it h 1947, p. 222.

U. Tuusula; Helsinki parish and Kerava (V.H.). - PS. Joroinen, Keriniemi (V.H.). - KemL. Sodan kylävillage (V.H.). - In a total 11 collections. Occurs from July to September in grass-herb forests amongst needles and herbaceous litter. Not earlier reported from Finland. $M$. capillaripes has in contrast to similar $M$. rubromarginata distinct »nitrous» smell, dark scattered pleurocystidia (seen under hand-lens as black points), and usually the colour of the pileus is paler.

\section{Mycena cineroides sp. $\mathrm{n}$}

Fig. 3 and 4.

Mycenae cinerellae similis, pileus $5-8 \mathrm{~mm}$ latus, $4-8$ $\mathrm{mm}$ altus, conicus, cinereus, lamellae latae distantes, basidia duabus sporis $11-14 \times 6-7 \mu$ praedita. Specimen typicum in Mus. Bot. Univ. Helsinki conservatum, legit V. Hintikka, prope Korso, Finland, 2?. 10. 56, n:o 429.

Pileus 5-8 $\mathrm{mm}$ broad, $4-8 \mathrm{~mm}$ high, narrowly and obtusely conic, often higher than its breadth, sometimes provided with an abrupt small umbo, the margin appressed against the stipe when young, surface smooth, hygrophanous, as moist striate nearly to the disc, ashy gray over the centre (Maertz \& Paul Pl. 14 G 4), the margin somewhat paler ( 11 C 3 ), when dry pale gray $(10 \mathrm{C} 2)$, without any brownish or yellowish shades. Context thin, grayish, odour and taste strongly farinaceous. Lamellae distant to subdistant, $10-16$ reach the stipe, very broad and distinctly decurrent, 

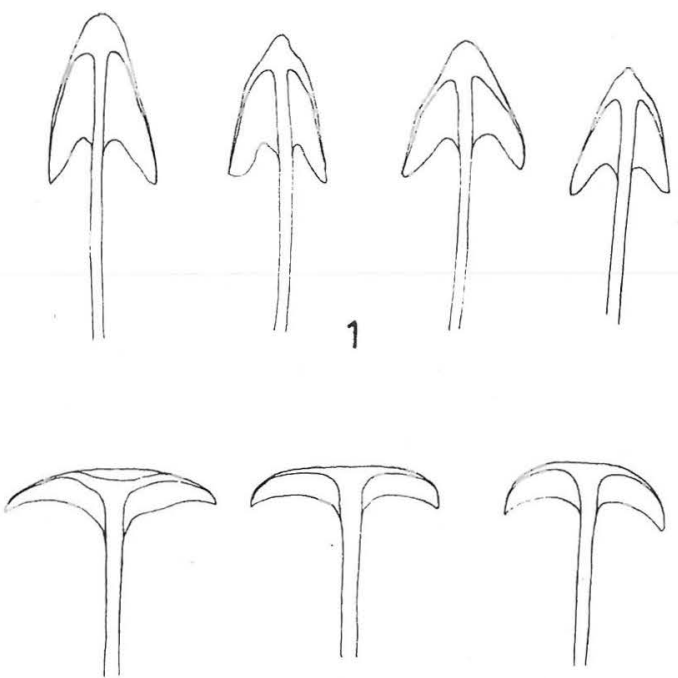

2
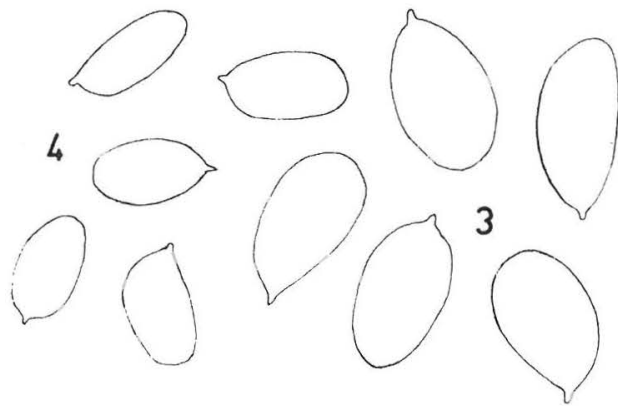

Fig. 3. Mycena cineroides: 1, pileus; 3 spores. $M$. cinerella: 2 , pileus; 4 , spores.

pale gray to whitish. Stipe $30-50 \times 0.5-1.0 \mathrm{~mm}$, equal or the base slightly enlarged, pale gray, when dry shining, fragile.

Spores $10-14 \times 6-7 \mu$, ellipsoid, amyloid, basidia 2-spored. Cheilocystidia abundant, clavate to subcapitate $8-12 \times 18-25 \mu$, apices covered with numerous rod-like projections, the cells of the lam.trama vesicular, about $35 \times 65 \mu$. Epicutis thin, $10-15 \mu$, the uppermost hyphae with short diverticulae, hypodermis well differentiated, cells 70 - $130 \times$ 15-30 $\mu$, content pale gray, the remainder of parallel filamentous hyphae (diam. $4-7 \mu$ ); oleiferous hyphae present.

U. Helsinki parish, Korso; Tuusula, Ruotsinkylä, Porvoo, Vessö; Hyvinkää (V.H.).

Occurs in mossy coniferous forests (VT, MT), often together with $M$. cinerella. In most cases they can be distinguished from each other already in the field by the shape of the pileus and the lamellae (fig 4).

\section{Mycena cinerella Karsten}

K üh n e r 1938, p. 368, S m it h 1947, p. 366. U. Tuusula, Ruotsinkylä; Helsinki parish, Korso; Sipoo (V.H.). - EH. Tammela, Mustiala (K a rste n 1889).

Occurs in mossy coniferous and mixed forests, in particular in moist spruce stands. Appears usually late in the autumn after the first frosts, but is at that time very abundant in the neighbourhood of Helsinki.

\section{Mycena citrinomarginata Gillet}

K üh n e r 1938, p. 409. S m it h 1947, p. 215. Fairly common in rich coniferous and deciduous forests in summer and fall from Ahvenanmaa (S chulmann 1961) to Inari Lapland (Ivalo, Toloskoski, V.H.). Not mentioned by K a r ste n, but his $M$. elegans probably includes this species.

\section{Mycena clavicularis (Fr.) Gillet}

K ühn e r 1938, p. 361, S m i th 1947, p. 429.

U. Helsinki, Pasila (R.T., H); Tuusula; Sipoo; Helsinki parish (V.H.). - EH. Vehkalahti, Summa (V.H.); Luumäki, Taavetti (V.H.). -

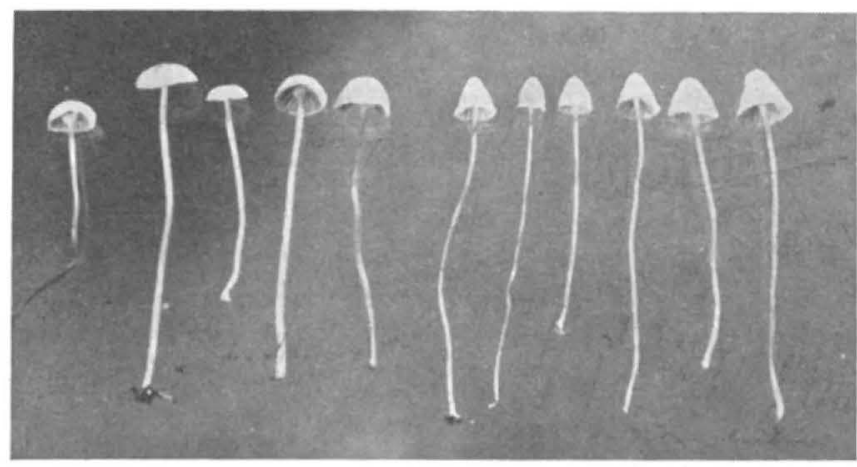

Fig. 4. Left: Mycena cineralla, right: $M$. cinoreides. 
EH. Urjala (M a l m s tröm 1960, p. 74, as $M$. vulgaris, H). Tammela (P.A.K., as $M$. vulgaris, H). PS. Joroinen (V.H.). - PP. Rovaniemi: Ylinampa, Vikajärvi, Sinettä, Olkkajärvi (V.H.). - KemL. Sodankylä (V.H.). - InL. Inari, $9 \mathrm{~km}$ south of the village (V.H.).

On the basis of these collections, $M$. clavicularis seems to be one of the most common Mycena-species in Finland. It grows in dry pine forests among pine needles, moss and Cladonia often in great quantities from July to October but is usually most abundant in August. Some collections are from pine bogs (Pasila), and occasionally it is met with also in moister spruce forests. In August 1958 it was between Rovaniemi and Sodankylä in mossy forests the most abundant agaric. $M$. clavicularis is often confused with $M$. vulgaris and $M$. pinetorum, and probably for this reason it has not been earlier reported from Finland.

\section{Mycena corticola (Pers. ex Fr.) S.F. Gray}

K ühn e r 1938, p. 245.

U. Helsinki, Herttoniemi (M ikko R a t ik a i n e n, V.H.); Espoo, Tapiola (M. K o r h on e n). - St. Tyrvää (P.A.K., H). - EH. Tammela (P.A.K., H).

Grows on the bark of living deciduous trees (Tilia, Acer etc.) in late autumn or early winter.

Mycena delectabilis (Peck) Sacc.

K ühner 1938, p. 663, S m it h 1947, p. 156.

A. Eckerö (Schulmann 1961, p. 29). V. Tammisaari (ibid. p. 29). - U. Tuusula, Ruotsinkylä (V.H.).

Met with in Ruotsinkylä in a drained swampy spruce forest and found there during several years.

\section{Mycena delicatella Smith}

Syn. M. lactea (Fr. ex Pers.) sensu Lange

K ühn e r 1938, p. 645, S m it h 1947, p. 161, L a n g e 1936, plate $53 \mathrm{~F}$.

V. Merimasku (P.A.K.). - U. Nurmijärvi, Kiljava; Hyvinkää, Jätinlinna; Helsinki parish, Korso (V.H.). - Sat. Tyrvää (P.A.K.). - EH. Tammela (P.A.K.). - EP. Pietarsaari (P.A.K.).

Occurs on needles under felling waste; two collections have been made in rich swampy forest. Th es l eff (1920) records $M$. lactea from »barrskog på öppna ställen, drifhus»; his collection in $\mathrm{H}$ from the latter biotope belongs, however, to the genus Coprinus. In $\mathrm{M}$ a $1 \mathrm{~ms} \mathrm{tröm}$ 's specimens $(1960$, p. 70) there are pleurocystidia present, probably belonging to $M$. pseudolactea, a species which I have not found in Finland.

\section{Mycena epipterygia (Scop. ex Fr.) S.F. Gray}

Very common at least in South and Central Finland north of Vaasa ( $\mathrm{K}$ a r s t e n 1889), Lapinlahti (Schulmann 1961) and Joroinen (V.H.). Occurs in moist woods of variable bonity with preference to places rich in felling waste and litter or rich in grass.

\section{Mycena epipterygia var. lignicola $\mathrm{S} \mathrm{m}$ it h}

S m i t h 1947, p. 428.

U. Tuusula, Ruotsinkylä; Hyvinkää, Jätinlinna (V.H.). - EK. Vehkalahti, Summa (V.H.) - PS. Joroinen Keriniemi (V.H.) - InL. Ivalo, Toloskoski (V.H.) - In total 12 collections.

Occurs in spruce or mixed forests (often Myrtillustype) in moss or emerging from rotten branches under moss carpet. This bisporous variety does not seem to be uncommon in Finland. It has not been earlier reported from Fennoscandia.

In Ruotsinkylä this species was found in 1956 growing in a moist spruce forest abundantly together with typical $M$. epipterygia and they were readily separable in field. In particular it is well characterized by is relatively small, umbonate, olivaceous brown pileus (Maerz \& Paul 14 G 6 and paler), yellow base of the stipe and large spores $(11-14 \times 6-8 \mu)$. The colour of the Finnish specimens agrees tolerably well with that described by S mith (1946) »citrine» to »dark citrine»; $\mathrm{Ridg}$ w a y's »citrine» is same as $14 \mathrm{~L} 6$ in $\mathrm{M}$ a e rtz \& Pau I.

Mycena epipterygia v. badiceps $\mathbf{M}$. Lge and. $M$ epipterygia v. brunneola Favre are very near this fungus, but studies based on fresh material are needed before their identity with this fungus can be established.

\section{Mycena erubescens Hohnel}

K ühner 1938, p. 230, S m it h 1947, p. 135.

V. Turku, Ruissalo, a group of basidiocarps on a rotten stump of Quercus. (V.H.). Specimens collected had abundant laticifers, granulous pleurocystidia and spores $10-11 \times 6-7 \mu$ from bisporous basidia.

$M$. erubescens has not been earlier reported from Finland. In Denmark it occurs according to $\mathrm{L}$ a $\mathrm{n}$ g e (1936) on stumps of oak and beech.

\section{Mycena fibula (Bull. ex Fr.) Kühner.}

K ühner 1938, p. 603, S m it h 1947, p. 121.

Common north to Lapland ( $\mathrm{K}$ a r s te $\mathrm{n}$ 1889). The northern-most collections are from Kola (P.A.K., H) and Sodankylä, Vaalajärvi (V.H.).

This species grows most often in moss in rich spruce swamps, occasionally in Sphagnum on shores of lakes or between Polytrichum etc. on sandy soil. 
Mycena flavo-alba (Fr.) Quel.

K ühn e r 1938, p. 548, S m ith 1947, p.166.

According to $\mathrm{K}$ arsten (1889), Schulma n n (1961) and my own observations fairly common in South and Central Finland. I have found it in North Finland from the following localities: PP. Rovaniemi, KemL. Sodankylä village; InL. Ivalo.

Occurs usually in small mossy meadows in woods, in grass in open forests, also in pure coniferous forests on needle beds.

Mycena galericulata (Scop. ex Fr.) S.F. Gray

Very common in South and Central Finland. The northhernmost collections are from EP. Vaasa (P.A.K., $\mathrm{M} \mathrm{a} 1 \mathrm{~ms}$ t $\mathrm{r} \ddot{\mathrm{m}}$ in $\mathrm{H}$ ) and Kuolla (P.A.K., HMF).

Occurs almost exclusively on rotten wood of deciduous trees (Alnus, Salix, Betula). Only once have I found this species on coniferous (pine) wood in Hyvinkää, Jätinlinna.

The colour of the gills varies greatly in different collections. In most cases they change their colour from whitish to reddish, but in some basidiocarps they become greyish. The spores of last-named pilei are slightly more elliptic than from reddish-gilled pilei $(10.9-13.0 \times 6.2-7.8 \mu$ vz. $9.3-11.7 \times 7.0-8.6)$ and the cap is not so distinctly striate as that of the preceeding form. Whether it is $M$. rugosa Fr., in which species gills become »ex albo cinereis» (F r i e s 1857, p. 208-209) and the firstnamed reddish-gilled $M$. galericulata Fr., in which gills turn »ex albo carneis», needs, however, further investigation.

\section{Mycena galopus (Pers. ex Fr.) Kummer}

Syn. M. galopoda auct.

Very common in moist coniferous forest with preference to small moist carpets of Sphagnum from June to October. The northernmost collections are from InL: Inari, Paaluniemi (TUR), Inari main village (V.H.) Sodankylä village (V.H.).

This species is regarded as rare by $\mathrm{K}$ a r s te $\mathrm{n}$ (1889) as well as by Rautavaara (1947); even S chu I ma n n (1961) has met the typically coloured form only three times. However, a part of Karsten's collections of $M$. debilis in $\mathrm{H}$ belong to this species.

The colour of the cap varies greatly. Var. leucogala is not uncommon on burned areas and on peaty ground on ditches, tracks, etc. at least to Koli (R.T., $\mathrm{H})$ in the north.

\footnotetext{
Mycena gracilis (Quel.) Kühner

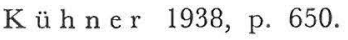

U. Helsinki parish, Korso, one collection from a rich spruce swamp under ferns and herbs. It showed typical narrow spores $(8.0-10.5 \times 2.0-2.5 \mu)$, long decurrent gills and indistinct $10-15 \mu$ long cheilocystidia. Not earlier recorded from Finland.

\section{Mycena griseoviridis Smith}

$\mathrm{S} \mathrm{m}$ it h 1947, p. 418.

U. Helsinki parish, Korso. One collection from mixed forest on the ground. The basidiocarps had cheilocystidia similar to those depicted by $\mathrm{S} \mathrm{mith}$ (l.c.)

\section{Mycena haematopus (Quel.) Kühn.}

K ühner 1938, p. 219, S m it h 1947, p. 140.

The main form as well as var. marginata are apparently fairly common at least in South and Central Finland on rotten twigs in soil, on logs and stumps, especially of decicuous trees. K a r s t e $\mathrm{n}$ (1889) mentions this species from »Nyl. - Lapl.», and the northernmost locality known to me is InL: Ivalo, Toloskoski, where I found the variety marginata.

\section{Mycena inclinata (Fr.) Quel.}

K ühn er 1938, p. 340, S m it h 1947, p. 338. V. Turku Ruissalo (P. Ka 11 i o, (TUR) M. La urila (1939), V.H., Korppoo (Eklund 1943) U. Helsinki parish, Tammisto (V.H.)

In Finland known exclusively from rotten stumps of Quercus and its distribution seems to be limited to the oak region on the southern coast. In Central Europe it is also recorded from rotten wood of other deciduous trees, also occasionally on coniferous wood ( $\mathrm{F}$ a v re 1960). In $\mathrm{H}$ there is a collection labelled $M$. inclinata made by $\mathrm{K}$ a $\mathrm{r}$ s t e $\mathrm{n}$ in Teisko in 1859, which is $M$. viscosa. However, $M$. inclinata is mentioned neither in $\gg$ Mycologia Fennica» nor in $»$ Kritiskt Öfversigt».

\section{Mycena iodiolens Lundell}

Syn. $M$. vitilis (Fr.) Ricken, $M$. filopes Lange

K üh n e r 1937, p. 298, S m i th 1947, p. 285. V. Turku, Muhkuri; Bromarv, Framnäs (V.H.) U. Helsinki parish, Korso (V.H.)

Occurs in grass-herb forests (oak or other broadleaved trees, occasionally under conifers), found also on garden soil emerging from small twigs buried in soil.

The odour of iodoform is not so strong as that of M. metata, but the species is well characterized by its hyaline hypodermis, which causes its colour change from gray-brown when moist into almost pure white when dried. Both two-spored and four-spored forms have been found. 
Mycena laevigata (Lasch) Quel.

K ühncr 1938, p. 494, S m ith 1947, p. 322.

Fairly common on old stumps and logs of conifers in summer and fall. Herbarium records confirm the opinion of $\mathrm{Karsten}$ (1889) and $\mathrm{R}$ a u t av a a $r$ a (1947), who state it as common to Lapland, where $\mathrm{K}$ arste $\mathrm{n}$ has collected it in Kuolla and the author in Inari, Myösäjärvi.

One of $\mathrm{K}$ arsten's collections of $M$. lactea belongs to this species.

\section{Mycena leptocephala (Pers. ex Fr.) Gillet}

$\mathrm{S} \mathrm{m}$ i t h 1947, p. 241.

Common from south to KemL. Sodankylä (V.H.) and InL. Ivalo (V.H.) in moist deciduous forests, in rich swamps and alder thickets, sometimes on meadows in grass or in Sphagnum. The pileus is usually dark gray and always with a distinct »nitrous» smell. The size of the basidiocarps varies greatly, approaching to $M$. praelonga and $M$. stannea, but all specimens which I have found have had the characteristic smell at least when the flesh was crushed.

\section{Mycena longiseta Höhnel}

K ühne r 1938, p. 173, S m it h 1947, p. 57.

U. Tuusula; Helsinki parish; Porvoo, Sondby (V.H.). — EH. Juupajoki (V.H.). - PH. Jyväskylä parish (V.H.). - PS. Joroinen (V.H.). - PP. Rovaniemi (V.H.)

$M$. longiseta is according to my experience the most common species of the section Basipedes in Finland. It occurs in mixed and coniferous forests on moss, litter and pieces of rotten wood, often emerging from the uppermost litter layers. Despite the fact that it is well characterized by thickwalled setae on the pileus and stipe, it is not previously reported from Finland. However, it seems improbable that earlier mycologists had overlooked it but for lack of herbarium material it is impossible to decide which name they have used for it.

\section{Mycena luteoalcalina Singer}

S in g e r 1931; p. 528, K ü h n e r 1938, p. 432.

Syn. $M$. alcalina Fr. $M$. viridimarginata v. lutea Favre?

U. Helsinki (P.A.K., as M. alcalina, H), Tuusula; Sipoo; Helsinki parish; Kerava; Hyvinkää (V.H.). - EH. Juupajoki, Hyytiälä (V.H.). - PS. Joroinen Keriniemi (V.H.). - PP. Rovaniemi town (V.H.). KemL. Sodankylä (V.H.). - InL. Inari village (V.H.); Utsjoki Kevo (T u r.).

Common on old stumps and rotten logs of coniferous trees apparently in the whole country.

This species is characterized by its beautiful yellow stipe, darker or lighter yellow-brown (centre 15 C 9 - margin 12 E 6) cap, fusoid- ventricose cystidia only on the edge, and by intercellular or membranaceous yellow pigment in the epicutis.

$M$. luteoalcalina has not been earlier reported from Finland. However, F rie s included it in his $M$. alcalina, because he described his alcalina as having a yellow stipe comparable in colour with $M$. epipterygia. The concept of $M$. alcalina according to $\mathrm{K} \ddot{\mathrm{uhner}}$ and L a nge refers to a distinctly different mushroom with gray vacuolar pigment in the hypodermis.

The edges of the lamellae are often bordered shortly on the distal part with the colour of the cap

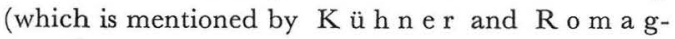
$\mathrm{n}$ e s i 1953). Occasionally this bordering, especially in old carpophores turns greenish, thus approaching $M$. viridimarginata Karsten. At present I have not been able to find any other differences between this and the typical $M$. luteoalcalina except slightly more olivaceous pileus (disc $15 \mathrm{H} \mathrm{5-14} \mathrm{I} \mathrm{5-6,} \mathrm{margin}$ 13 H 6.)

\section{Mycena maculata Karsten}

K ühne r 1938, p. 334, S m it h 1947, p. 341. U. Tuusula, Ruotsinkylä; Helsinki parish (V.H.). EH. 'Tammela (P.A.K.).

Fairly common ( 26 collections) in the surroundings of Korso on rotten stumps of conifers.

\section{Mycena megaspora Kauffman}

K ühn e r 1938, p. 329, S m it h 1947, p. 296. - U. Tuusula Ruotsinkylä; Helsinki parish; Kerava; Sipoo Spjutsund (V.H.). - EK. Hamina town (V.H.). - EH. Loppi, Pilpala (V.H.) - PS. Joroinen, Lahnalahti (V.H.) - InL. Utsjoki, Vetsikko (V.H.)

All my 12 collections are made from peaty soil, e.g. dry pine bogs, drained spruce swamps, often beneath paths or drainage ditches. Both $\mathrm{Favre}$ (1948) and S m it h (1947) report this species from swampy soil.

I had this species in pure culture on Picea wood in a $500 \mathrm{~cm}^{\prime}$ bottle. It produced after a year some typical dark-coloured basidiocarps and some others 18 months after inoculation, which, however, were all sterile. In addition to other morphological charactericstis (spore size, pseudorhiza) this indicates that $M$. megaspora is distinct from other species of the Rigipedes-group.

\section{Mycena metata (Fr. ex Fr.) Kummer}

Syn. $M$. vitrea v. tenella Kühner, non $M$. metata Kühner. 
Kühner 1938 p. 289, S m it h 1947, p. 272.

Very common in South and Central Finland in moist and dry coniferous forests. The northernmost collections are from KemL. Sodankylä, Vuotso (V.H.).

Characteristic by more or less pronounced reddish colour of the pileus, fairly evenly distributed dark pigment in the cap trama and by its odour, which after specimens have been gathered, becomes reminiscent of iodoform.

Mycena mirata (Peck) Sacc.

K ühn er 1938, p. 282, S m i t h 1947, p. 113.

V. Turku, Ruissalo (V.H.), one collection growing on a mossy log of Quercus.

\section{Mycena niveipes Murrill}

\section{Syn. $M$. pseudogalericulata Lge}

K ühn e r 1938, p. 485, S m i th 1947, p. 310.

A. (S chulmann 1961). - V. Tammisaari (S c h u l m a n n 1961); Ruissalo (V.H.); Pyhäjärvi U.l. (V.H.). - U. Tuusula and Helsinki parish (V.H.). - EK. Parikkala (S c h u l m a n n 1961). - PS. Joroinen (V.H.); Lapinlahti (S chulm a n n 1961). - InL. Ivalo, Toloskoski (V.H.).

Fairly common from June to October, particularly in alder woods on rotten twigs, stumps or on soil.

\section{Mycena oregonensis Smith}

S m it h 1947, p. 117-118.

Notes on Finnish material: Pileus $5-8 \mathrm{~mm}$, with a distinct umbo, bright orange yellow, lamellae decurrent, edge orange, stipe fragile, pale yellow, hairy. Sp. $7.5-9.0 \times 3-4 \mu$, cheilocystidia fusoidventricose, content yellow, pleurocysyidia abundant, yellow. Epicutis thin, diverticulate, caulocystidia similar to cheilocystidia, abundant.

Met with only in one locality: U. Sipoo, Myyras, abundant during three years in a fern-rich swampy spruce forest among moss and litter.

Mycena parabolica (Fr.) Quel.

$\mathrm{S} \mathrm{m}$ i t h 1947, p. 302.

U. Helsinki parish, Korso, several collections. (V.H.).

On rotten twigs or logs in moist forests.

The shape of cheilocystidia is quite variable and intergrades sometimes into that of $M$. alcalina, which may have roughened cystidia on the distal end of the lamellae.

\section{Mycena pearsoniana Dennis ex Singer}

U. Tuusula, Ruotsinkylä (V.H.).

Met with in moist Alnus glutinosa- swamps and grass-herb forests.
Mycena polygramma (Bull. ex Fr.) S. F. Gray

K ühne r 1938, p. 498, S m it h 1947, p. 292.,

A. Lemland (Sten Iid 1947). - V. Turku, Ruissalo (P.A.K.), Muhkuri (V.H.); Bromarv, Framnäs (V.H.); Karjalohja (M. L a u r i l a 1939), Korppoo (E k l u n d 1943). — U. Helsinki, Östersundom (V.H.). - EH. Tammela (P.A.K., H).

Seems to be restricted to oak woods and luxuriant grass-herb forests, where it grows on naked humus earth or around stumps and leaf-heaps.

\section{Mycena pseudocorticola Kühner}

K ühner 1938, p. 243.

U. Espoo. Otaniemi, 8.XII 1960 on bark of deciduous trees (M. Korhon e n); Helsinki, Herttoniemi (V.H.).

\section{Mycena pterigena (Fr. ex Fr.) Kummer}

U. Helsinki (R.T., H); Tuusula and Helsinki parish (V.H.). - St. Kankaanpää (M. L a u r i l a, H). - EH. Messukylä (P.A.K., H); Tammela, Mustiala (P.A.K., H).

Found exclusively on old leaves of ferns (Athyrium filix-femina, Dryopteris spinulosa and Matteuccia struthiopteris).

\section{Mycena pura (Pers. ex Fr.) Kummer}

Very common in moist and particularly in grassherb forests (OMT) from June to October. According to $\mathrm{K}$ a r ste $\mathrm{n}$ common to Lapland, where I have found it in Inari.

M. pura v. alba is met with once in a rich alder stand in Helsinki parish, Rekola.

M. pura v. rosea Schum.-V. Bromarv, Framnäs, 28.X.1958, in a oak wood among leaf litter.

Mycena purpureofusca (Peck) Sacc.

S m i th 1947, p. 209.

U. Tuusula, Ruotsinkylä (V.H.) - PS. Joroinen, Keriniemi (V.H.)

Found on old logs in moss and on alder stumps. The colour of the cap of my specimens was M. \& P. $6 \mathrm{~F}-\mathrm{G} 8$, the margin $4 \mathrm{~F} 8$. The material present, however is too small to distinguish between $M$. elegantula Peck and this fungus.

\section{Mycena rigidula Karsten}

Symb. ad Mycol. Fenn. VI.

U. Tuusula, Hyrylä (V.H.). - EH. Tammela (P.A.K.).

The carpophores found by me were growing in a felling area among lumbering remains, leaf litter and wood chips. Pileus was shining gray when dry, sporea s 7.0-8.5 $\mu$, spherical, basidia 4-spored. They differed from $\mathrm{K}$ a r s ten's description by having a dark stipe (according to $\mathrm{K}$ arste $\mathrm{n}$, 
white). M. salicina Vel. (K ü h n e r 1938, p. 620) is very close to this fungus differing mainly by having 2-spored basidia. Unfortunately, there are no $\mathrm{K}$ arsten's collections left to decide the number of spores in them. I have used $\mathrm{K}$ a r s t e n's name mainly because of the conspicuously shining surface of the pileus, which $\mathrm{K}$ a r s t e n emphasizes, and the discrepancy in the number of spores borne in basidia in $M$. salicina.

Mycena rorida (Scop. ex Fr.) Quel.

Fairly common, often already in June in moss in coniferous forests, often emerging from rotten branches of small twigs of dwarf schrubs. $\mathrm{K}$ a $\mathrm{r}$ s t e $\mathrm{n}$ (1889) reports this species as common from Uusimaa to Lapland and the northernmost collections are from Kuolla (P.A.K.), Inari village and Kaunispää, $350 \mathrm{~m}$ s.m. in a sub-alpine birch forest (V.H.)

\section{Mycena rosella (Fr.) Kummer}

According to $\mathrm{K}$ arsten (1889) common frum south to Vaasa (EP) and $\mathrm{Schulmann}$ has found it in Parikkala (ES). Found in the neighbourhood of Helsinki in moist coniferous forests in most cases under pine.

\section{Mycena rubromarginata (Fr. ex Fr.) Kummer}

N. Helsinki parish and Tuusula (V.H.). - EH. Tammela (P.A.K.,). - PS. Joroinen (V.H.).

Probably common in South Finland, but it has been confused with $M$. capillaripes. Characteristic of this species is its occurrence on small rotten branches or logs of conifers, more rarely on old stumps.

Mycena sanguinolenta (Alb. \& Schw.ex Fr.) Kummer

Common from south to $\mathrm{KemL}$. Sodankylä village (V.H.). Gregarious in moist coniferous forests (MT-OMT) and in swampy spruce forests from July to October.

\section{Mycena speirea (Fr.) Gillet}

K ühner 1938, p. 582, S m ith 1947, pp. 359-360.

U. Tuusula and Kerava (V.H.). - InL. Ivalo, Toloskoski (V.H.).

Met with in rich swampy forests under ferns or in moist herb-rich forests on rotten pieces of wood in summer and fall.

\section{Mycena strobilicola Favre \& Kühner}

K ühner 1938, p. 461.

V. Vihti (R.T., H) ; Parainen (M. K or h on e n). - U. Helsinki (R.T.); Espoo (R.T.); Tuusula (V.H.). - EH. Hattula (L. H a k a l a, H).

Occurs on rotten cones of spruce in the spring.
It seems in the light of the present material to be clearly distinct from $M$. alcalina and $M$. plumbea by its undifferentiated hypodermis and more yellowbrown colours.

\section{Mycena stylobates (Pers. ex Fr.) Kummer}

K ühne r 1938, p. 186, S m it h 1947, p. 53.

V. Merimasku (P.A.K.). - U. Tuusula and Helsinki parish (V.H.). - EH. Tammela (P.A.K.). ES. Konnunsuo (P.A.K.). - KK. Jääski (P.A.K.). - Lp. Kola (P.A.K.).

Occurs in moist forests on litter, pieces of wood, particularly under heaps of branches etc.

\section{Mycena Srortzii (Fr.) Smith}

Met with in grass-herb forests, often in Rhodobryum, and is common in the South and Central Finland, the northernmost collection is from Sodankylä, Vaalajärvi (V.H.).

\section{Mycena tintinabulum (Fr.) Schroeter}

K ühn e r 1938, p. 337

V. Tammisaari (Schul mann 1961, p. 26, H).

\section{Mycena urania (Fr.) Gillet}

K ühne r 1938, p. 310, S m it h 1947, p. 270.

U. Helsinki parish; Tuusula (V.H.). - KemL. Rovaniemi, near airport (V.H.). - InL. Ivalo, Toloskoski (V.H.).

Collected in drained spruce swamps, mixed birchspruce forests (MT), in Larix plantations and once in a dry pine plantation (VT). Both $\mathrm{K} \ddot{u} \mathrm{hner}$ and $\mathrm{Smith}$ (1.c.) mention this species from swampy forests in moss and on leaf litter. It is not earlier recorded from Finland.

\section{Mycena viscosa (Secr.) Maire}

K üh n e r 1938, p. 351, S m ith 1947, p. 421.

A. Lemland (S t e n li d 1947) - U. Tuusula, Ruotsinkylä; Helsinki parish (V.H.). - EH. Teisko (P.A.K., H).

Fairly common near Helsinki on the base bark of living spruces or on stumps, probably also elsewhere in South Finland.

\section{Mycena vitilis (Fr.) Quel.}

K ühner 1938, p. 504, S m it h 1947, p. 288. V. Turku, Ruissalo and Muhkuri (V.H.). - U. Tuusula, Ruotsinkylä; Porvoo, Tamminiemi (V.H.). - PS. Joroinen, Keriniemi (V.H.).

Met with in broad-leaved or mixed grass-herb forests, in drained spruce swamps etc., often emerging from rotten pieces of wood buried in soil. 
For financial support I wish to express my thanks to the Foundation of Osk. Huttunen (O s k. H u tt u s e n $\mathrm{S}$ ä ät i ö) and to the Society $\mathrm{S}$ u o m a 1 a i- nen Eläin- ja Kasvitieteellinen Seura Van a mo (»Vänrikki Matti Laurilan rahasto»).

\section{LITERATÚRE}

E k 1 u n d, O., 1943: Zur Pilzflora des Schärenarchipels SW-Finnlands. - Mem. soc. Fauna et Flora Fennica 18, 2-21.

F a vre, Jules, 1948: Les associations fongiques des haut-marais Jurassiens et de quelques régions voisines. - Materiaux pour la flore cryptogamique Suisse, 10:3, 1--228.

- 1960: Catalogue descriptif des champignons supérieurs de la zone subalpine du parc national Suisse. Erg. der wiss. Untersuchungen der Schw. Nationalparks 6 (neue Folge), $1-610$

F r e y, R., 1944: Några anteckningar om basidsvampfloran på Åland. - Mem. Soc. Fauna et Flora Fennica 19, 9-16.

Fri es, E 1 i a s M., 1857: Monographia Hymenomycetum Sueciae I. - 484 pp. Upsaliae.

K a r s t e n, P. A., 1879: Rysslands, Finlands och den skandinaviska halföns hattsvampar. - $571 \mathrm{pp}$.

—- 1889: Kritisk öfversigt af Finlands basidsvampar. - Bidr. till kännedomen af Finlands natur och folk 48, $1-470$.

K üh n e r, R ob e r t, 1938: Le genre Mycena. Encycl. Mycol. 10, 1-710.

$\longrightarrow$ \& H. Romagnesi, 1953: Flora analytique des champignons supérieurs. - Paris, $1-557$.

L a n g e, J. A., 1936: Flora Agaricina Danica, vol. II, $1-105+40$ plates. Copenhagen.
L a n g e, M or t e n, 1948: The agarics of Maglemose. - Dansk Bot. Arkiv. 13:1, $1-141$.

L a u ril a, M a t i, 1939: Basidiomycetes novi et rariosque in Fennia collecti. - Ann. Bot. Soc. Zool.-Bot. Fennia »Vanamo» $10,4: 1-24$.

L undell, Seth \& J. A. Nannfeld t, 1942: Fungi exiccati Suecici, praesertim Upsaliensis. - 44 pp. Upsala.

$\mathrm{M}$ a ertz, A. \& M. R e a P u l, 1950: A Dictionary of color. - $208 \mathrm{pp}$. New York.

M a 1 m ström, N., 1960: Tutkielma LounaisHämeen sienistä v. 1958. - LounaisHämeen Luonto 8, 65-81.

R a u t a va ra, T., 1947: Suomen Sienisato. -534 pp. Porvoo.

$\mathrm{Schu} 1 \mathrm{~m}$ a nn, O. v., 1961: Zur Kenntnis der Basidiomyceten Finnlands. - Karstenia V, 5-99.

$\mathrm{S} \mathrm{m}$ i t h, A l ex a n d e r H., 1947: North American species of Mycena. - $521 \mathrm{pp}$. Ann Arbor.

S t e $n 1$ i d, G., 1947: Några anteckningar om Ålands svampflora. - Mem. Soc. Fauna et Flora Fennica 23, 82-90.

Thes leff, A., 1920: Studier öfver basidsvampfloran i sydöstra Finland. - Bidr. till kännedomen af Finlands Natur och Folk 79, 1-140.

T u o mik oski, R is to, 1953: Notes on Finnish Agaricales. - Karstenia 2, 26-32. 